\title{
Poul Holm \\ Human impacts on fisheries resources and abundance in the Danish Wadden Sea, c1520 to the present
}

\begin{abstract}
For the past 30 years, the Danish Wadden Sea area has been protected by fishery and hunting regulations, pollution controls and settlement restrictions. Nevertheless, today's Wadden Sea is a depleted ecosystem when we compare it with past abundance and diversity of marine animal populations. This review indicates that the abundance of finfishes has undergone a long-term decline since the seventeenth century. The review also indicates a trajectory of ecological decline since the early twentieth century that seems to be related to: (1) fishing extractions which focused on undersized fish throughout the first half of the twentieth century; (2) habitat destruction, which was most marked in the first half of the twentieth century; and (3) pollution, which was worst in the third quarter of the twentieth century. Historical investigation reveals that we need to fundamentally revise present-day baselines about the potential species richness and abundance of the Wadden Sea.
\end{abstract}

Keywords Wadden Sea - Denmark - Ecosystem · History $\cdot$ Fisheries

\section{Introduction}

The Danish part of the Wadden Sea comprises the area from Blåvand with the Reef of the Horn in the north to the German border. The major tidal inlets are the Grådyb to Ho Bay and the town of Esbjerg, the Knudedyb between the islands of Fanø and Mandø, and Listerdyb between the islands of Rømø and Sylt, Germany. This is an area that was and is relatively less

Communicated by H.K. Lotze and K. Reise

P. Holm

Centre for Maritime and Regional Studies,

University of Southern Denmark, Denmark

E-mail:pho@hist.sdu.dk

Tel.: + 45-6550-4150

Fax: + 45-6550-1091 populated by humans than the German and Dutch parts of the Wadden Sea, and yet an investigation of the history of fisheries in the region indicates that there have been profound human-induced changes to the ecosystem in past centuries. This paper reviews human impacts on marine life, mainly fish, shellfish and seals, in the Danish section of the Wadden Sea. It focuses on fisheries and other extractions, but also indicates points in time when habitat changes, pollution and protection measures have had sudden effects on the marine environment. The historical scope of the paper is from the late Middle Ages to the present. A review of this sort has not been undertaken before. Current management of the Danish Wadden Sea therefore lacks an understanding of the significant changes to marine life which have occurred in recent decades and centuries, and conservation goals are set with no knowledge of how much we have lost.

\section{Methods}

For recent decades, this review is largely based on published scientific papers and reports on the Danish Wadden Sea. I have also used my own interviews with Danish fishermen, conducted for the Fiskeri-og Søfartsmuseum, Esbjerg in 1987 (Holm 1988). For the nineteenth and early twentieth centuries, I have based the review on a wide array of material, from fish inspector's reports and published oral histories, to archival material at the Fiskeri-og Søfartsmuseet. Due to the qualitative nature of most of these sources, we can get information about species richness, but little information about species abundance for the modern period. The fisheries of the sixteenth and seventeenth centuries are largely documented through archival research by Maibritt Bager and myself. While statistical information on fishing effort and landings is, strangely, almost absent from recent centuries, the tax records of the early modern period allow for some quantification of fishing effort and an indication of changes in species abundance. 
This paper is organized in a chronology from the present back to the sixteenth century in order to highlight the significance of pushing back the baseline of our knowledge of the fisheries. Current ecological literature reveals a lack of knowledge of past biodiversity and abundance levels, and this overview is intended to provide a first attempt at redressing this imbalance. Much archival and archaeological evidence awaits future researchers.

\section{Results}

\section{Exploitation and protection 1970-today}

Today, there is no commercial finfish fishery in the Danish Wadden Sea. The last full-time fisherman ceased fishing in 1986: in 1987 the use of gill-nets was forbidden throughout the Danish part of the Wadden Sea, and the last part-time fisherman using nets and rouses for eel (Anguilla anguilla) and sea trout (Salmo trutta) gave up his license in the 1990s (Holm 1988, 1994).

The only current professional fishery is for mussel (Mytilus edulis) and cockle (Cerastoderma edule). In the 1980 s, the mussel fishery landed about 20,000 tonnes per year but overfishing and population losses due to two heavy winters caused a licensing regime to be implemented. Nevertheless, the mussel beds south of Esbjerg have either not regenerated at all, or only to a much depleted level. The mussel beds in Ho Bay and northern Grådyb did recover and, as a consequence, the overwintering eider bird population has concentrated in the bay. The Ho Bay fishery has been allowed in the past decade to harvest up to between 3,000 and 10,000 tonnes per year (Kristensen and Pihl 2003). The fishery for cockles is a recent development, and while the first beds to be fished seem depleted, new beds in the Grådyb area have been identified and are being fished to a level of around 500 tonnes per year (Kristensen et al. 2002).

Shrimping (for Crangon crangon) was introduced to the Danish Wadden Sea in the 1960s, and by the late 1970s comprised about 30 vessels. Due to conservation concerns, the entire Danish Wadden Sea area was closed to fishing in 1977 and the regulation is still in force (Kristensen and Hedegaard 2002). Nevertheless, shrimpers have been sighted fishing inside the island of Fanø.

The distinct local populations of Atlantic salmon (Salmo salar) in the Varde and Ribe rivers were long thought to be extinct, but genetic analysis has shown that the Varde river still hosts a remnant run of salmon that have a similar genetic profile to fish caught in the river in the 1920s. A genetic pool of Ribe salmon also seems to be in existence, while the population in another Danish river system, Storåen, seems to have gone extinct (Nielsen and Koed 2000). The causes of the decline of the Varde salmon are not known as there is no available time-series for the population. The river was largely blocked to salmon by the establishment of Nørholm mill in the Middle Ages, and the effects of the hydropower installation and a fish ladder in the 1950s are disputed (M. Guldberg, personal communication). Recent investigation has hypothesized that the stock may have established new, hitherto unidentified spawning grounds south of the hydropower station as few fish manage to pass the fish ladder. A large proportion of the genetically sampled salmon population was identified as straying Swedish, Scottish or Irish salmon (Jepsen et al. 2003).

There is no study available of salmon and sea trout populations through the twentieth century for the Danish Wadden Sea area. Commercial catches for two northwest Jutland river systems, Skjern $\AA$ and Storå, declined from a level of around 2,000 salmon and 2,500 sea trout after 1910 to insignificance after 1970. Reductions were caused mainly by habitat changes such as the building of drainage canals in the nineteenth century, and hydropower installations and fish dams in the twentieth century, while the effects of fishing are unclear. The success of recent conservation measures cannot yet be estimated (Dieperink 2002). Possibly, the population dynamics of the Varde, Ribe and Vidå rivers have followed the same pattern as the one described for the West Jutland rivers.

The Danish Wadden Sea has a population of harbour seals (Phoca vitulina) and grey seals (Halichoerus grypus). The harbour seals have been effectively protected since 1977 both from hunting and habitat disturbances, and reached a maximum population size by 1988 at around 2,700 individuals. A seal disease phocine distemper virus caused the loss of $60 \%$ of the population in 1988, and a repeated outbreak in 2002 may have caused the loss of half the population. The seals have shown a strong regeneration ability, and human impact seems to have been minimized by protection measures (Udkast 2002). Other marine mammals, such as the grey seal (Halichoerus grypus) and the harbour porpoise (Phocoena phocoena), occur in the Wadden Sea only as stray visitors, as does the sperm whale (Physeter macrocephalus) which did, however, occur in two mass strandings in 1996 and 1997 of a total of 29 individuals.

Following the introduction of protective measures in the 1970s and 1980s, commercial finfisheries and seal hunting have been given up in the Danish Wadden Sea area. However, the shrimp fishery rose to considerable importance in this period, and while it has now been banned, there is still evidence of active fishing. The mussel beds have been heavily impacted in the last couple of decades, and the activity is still spreading. Overall, however, the recovery of the seals and the increase in strandings of sperm whales have been taken to indicate a healthy recovery of the ecosystem. The question remains whether this picture holds true when we compare with evidence for past species richness and abundance.

Habitat transformation, pollution and exploitation, early-mid twentieth century

Contrary to the German and Dutch parts of the Wadden Sea, the building of dikes and dams is a fairly recent 
Fig. 1 Dikes and sluices in the Danish Wadden Sea region, from LANCEWAD (2001)

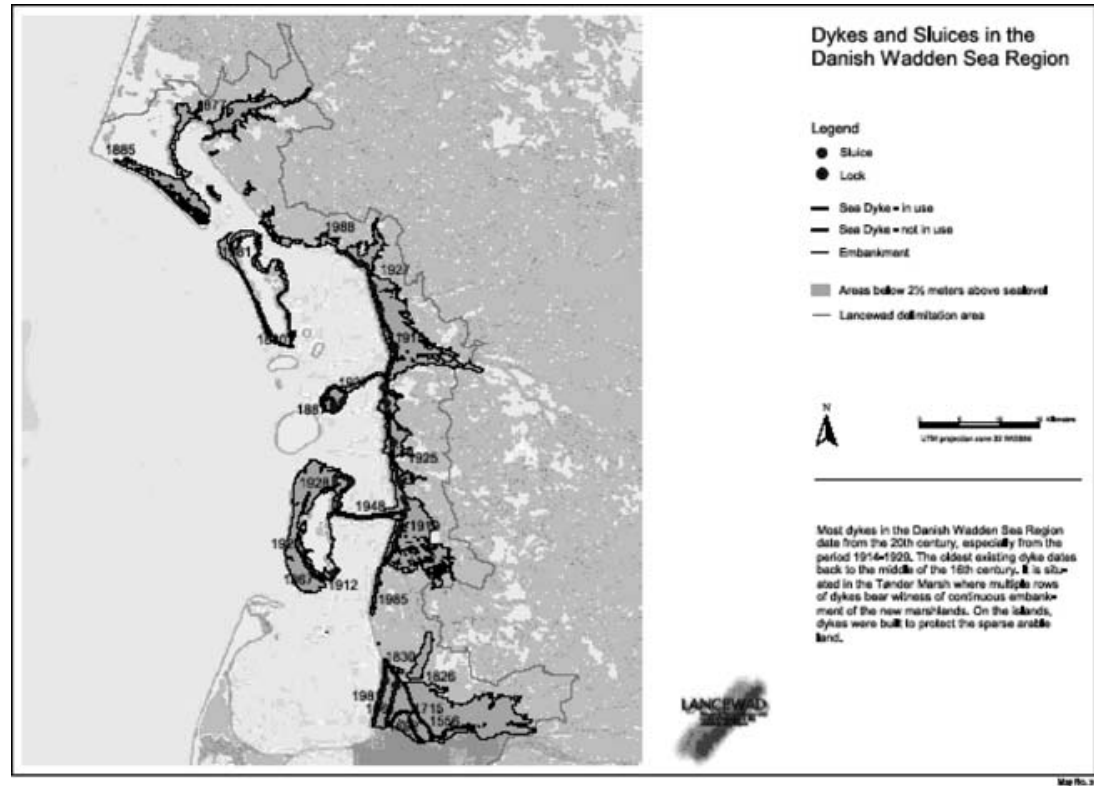

phenomenon (LANCEWAD 2001). The map (Fig. 1, LANCEWAD 2001) shows that even today the northernmost part of the area is free of dikes except for small inland barriers, and that the southern parts of the Vidå and Ribe rivers were only diked in the beginning of the twentieth century.

The consequences to the local fishing population of the diking and draining of the vast Vidà system in the 1930s are documented in a comprehensive series of interviews (Møller 1973). The marsh people depended entirely on the use of boats for transportation, and the fishery was essential for home consumption as well as for income. No good landing statistics are available, but the interviews carried out in the 1960s bring out reminiscences of a river full of eel, in addition to salmon, sea trout and houting (Coregonus oxyrinchus) and many freshwater species. The river was so plentiful that the fishermen did not rely on the Wadden Sea apart from for plaice (Pleuronectes platessa) which was caught by small trawls for home consumption.

For the Wadden Sea islands and coastline, we have few interviews with fishermen and no good statistics. Beam trawling was introduced to the Danish Wadden Sea by German fishermen from Blankenese who visited the area and used the trawl from c1800 onwards (Holm 1992). Local fishermen adapted the use of the trawl around 1890 when it was in use in Esbjerg. Between the 1890s and 1950, small beam-trawling dinghies (open sailboats with 2-4 men) fished regularly for undersized plaice and dab (Limanda limanda) in the Grådyb during winter months. Official fishery statistics for 1899 document that 110 dinghies were active in the fishery. The importance of the Wadden Sea fishery is brought out by the fact that the commercial value of their catch in that year was $20 \%$ of total Esbjerg catches at a time when Esbjerg was the second-largest commercial fishing port in the country (Holm 1992). By 1900, the number of dinghies had risen to 150 but conservation concerns caused the authorities to ban the fishery by 11th December of the same year. It is unknown to what degree fishing was undertaken in later years, but through the 1930s the dinghy fishery with beam trawls was considered an important source of income to the unemployed, using an estimated number of 50 boats of between 1 and 3 metric tonnes. Other catch methods, such as a small iron ring net ('ringtogger'), were also commonly in use till mid-century and may even occasionally be used today (Holm 1988).

The dab fishery effectively came to an end around 1950. Contemporary observers were in no doubt that the contamination of Grådyb and Ho Bay by lubricants from the new fishmeal plants was to blame. The contamination was so bad that the live fish auction which operated hundreds of boxes in a special section of the fishing port had to close in 1957 (Holm et al. 1998). In a desperate move to survive, the Association of SmallBoat Owners, which represented the dab fishermen, got permission to land undersized herring (Clupea harengus) for the fishmeal factory. Nevertheless, the Association was dissolved in 1956 (Holm 1988). Lubricant contamination was drastically reduced in the 1970 s and eliminated in the $1980 \mathrm{~s}$, but the dab stock has not regenerated. In the 1980s, a short-lived outburst of undersized dabs was the target of a commercial fishery which was later found in court to be contrary to fisheries regulations. Observations by the crew of the museum vessel of the Fisheries and Maritime Museum, Esbjerg, which conducts small daily trawling operations for education purposes, indicate that species composition and abundance of small dabs and plaice have declined markedly since the 1980s (L.B. Thygesen, Fisheries and Maritime Museum).

The salmon and eel fisheries were also of considerable importance through the first half of the twentieth cen- 
tury. Trap technology was introduced to the region in the 1830s by fiord fishermen from Ringkøbing and it spread rapidly with the use of cotton from the 1880s. "It's something new, and it pays well", a fishermen declared in 1891 (Holm 1992). By around 1900, the use of hundreds of traps caused the authorities to introduce protection zones around the mouths of rivers. In 1916, pound nets were introduced in the Grådyb area, and spread around the coast through the 1920s and the 1930s. The traps were operated by a dozen fishermen who squatted semipermanently in small wooden houses behind the dykes and flood-gates that were built at Ribe and Sneum rivers in the early twentieth century. The lock-keepers specialized in catching elver, of which several hundred kilos were exported annually, mainly to Sweden (Holm 1988). Due to the lack of quantitative data, we cannot accurately compare the size of the salmon, eel and elver fisheries with current abundance, but we may note that today only a few eel traps remain in operation by leisure fishermen in the Danish Wadden Sea.

The largest fishing company in the 1920s and 1930s was operated by Mads Langli, Esbjerg. He ran a small fleet of open and decked boats that fished throughout the region for a diversity of species. In Listerdyb, between Sylt and Rømø, his fishermen were able to catch sturgeon (Acipenser sturio) up to a size of $100 \mathrm{~kg}$, in addition to ray (Raiidae), brill (Scophthalmus rhombus), turbot (Psetta maxima) and spotted dogfish (Scyliorhinus stellaris and S. canicula). In Ho Bay the catches were herring (Clupea harengus) and salmon, which according to later interviews with the fishermen could be up to 15$20 \mathrm{~kg}$, and at the mouth of Sneum river near Ribe he competed with local professional fishermen for catches of herring and eel. In the Grådyb, mackerel (Scomber scombrus) catches were not uncommon, as was some sealing throughout the area (Holm 1992).

Moving our perspective of time back two or three generations, it becomes apparent that there have been significant changes to marine life in the Danish Wadden Sea. The main drivers of change would appear to have been diking, pollution and fishing. Diking of the southern part of the region caused the loss of vast wetlands and the closure of river systems to migratory fish. The fishmeal production of the 1950s and 1960s caused severe lubricant pollution in the northern part of the area which parallels in time the demise of the previously abundant dab population. The decline of this stock would also have been impacted by the massive fishery for under-sized dab and plaice which took place through the first half of the twentieth century. Larger fish, such as sturgeon, ray, brill and turbot, which were caught in significant quantities in the 1920s, had all but disappeared by the middle of the century but the reasons are not clear.

Fisheries history, 1770-1930

In the mid-nineteenth century, a considerable fishery for haddock (Melanogrammus aeglefinus) developed from the open shore at the villages of Nordby on Fanø and Hjerting in Ho Bay some $10 \mathrm{~km}$ north of Esbjerg (Holm 1992). The open boats used for hand-lining allowed for short trips into the Grådyb channel. However, by 1872 the fishermen began operating from small decked vessels with long lines that were introduced from personal experience with the Grand Banks fishery. The fishery proved very successful and generated good catches of haddock from the northernmost part of the Wadden Sea area at the Reef of the Horn. The number of fishers in Nordby and Hjerting grew from around 100 in 1859 to 134 men in 1885, and landings peaked at 617 metric tonnes in 1890. The good years were soon to end. By the late 1890 s, the haddock fishery was reduced to a few boats, while most fishermen now engaged in the North Sea plaice fishery outside the Wadden Sea or tried their luck with the developing dab and small-plaice fishery in the Grådyb mentioned above. The reason was a combination of poor catches and low prices of haddock. After the turn of the century, however, the price of haddock rose sharply, but the landings stayed poor. After 1906, the haddock stock did seem to be recovering and the fishermen were quick to resume their catches. Soon, however, the landings were depressed again. The haddock fishery continued at a low level until the First World War, but by the 1920s the catches were minimal, and the last vessel to abandon long-lining laid up around 1930 (Holm 1992).

For the south-eastern North Sea, we have evidence of an abundant haddock fishery by German handliners off the island of Helgoland in the late eighteenth century and first half of the nineteenth. Statistics show substantial catches by 1875 declining rapidly in the last quarter of the century to nil around 1910 (Lozan 1990, 1994; see also Lotze 2005). We do not have a similar long run of catches for the Danish Wadden Sea, but qualitative evidence from the island of Fanø does indicate the existence of a substantial haddock fishery from the 1770s until the second half of the nineteenth century (Kromann 1934). It would seem that the Wadden Sea and southern North Sea haddock stocks were rendered commercially extinct by the intensive German and Fanø-Hjerting fisheries of the late nineteenth century. Today, haddock is prevalent mainly in the northernmost part of the North Sea and in the Skagerrak (Hedger et al. 2004).

\section{Fisheries history, 1650-1770}

The seventeenth and eighteenth century fishing effort was at a very low level compared to the nineteenth century, probably mainly due to the fact that markets and commercial fishery operations were largely undeveloped. The oyster beds, which were of considerable importance to the Danish crown during this period and into the nineteenth century, were located south of the modern German border and, therefore, will not be treated in this paper (but see Lotze 2005). 
The main fishery throughout the area seems to have been for plaice and dab with semi-permanent wicker traps ('hammer') (Holm 1988). The traps had very extensive wings which trapped the fish when they followed the out-going water at low tide. Also the ring nets ('ringtogger') and other small, hand-operated gear were used mainly for subsistence fisheries. We have no information of fisheries for other species than the ones that we know for the nineteenth century.

\section{Extractions, 1450-1650}

A much larger fishing effort is documented for the late medieval and early modern period. The effort was at a scale which was certainly comparable to the late nineteenth century and was probably even higher. The documentation for the late medieval period is scanty, but it does suggest that the fisheries built up through the fourteenth and fifteenth centuries to be at a very high level when sixteenth-century sources allow us to gauge their importance (Holm 1999).

The first good evidence comes from outside the region. In the fifteenth and sixteenth centuries, the island of Helgoland attracted German and Danish fishermen from the Wadden Sea region for the schools of herring which could be caught during August and September. Surviving tax accounts from 1513 show around 1,500 visiting fishermen during the herring season, 425 of them coming from the present Danish part of the Wadden Sea. Seven years later, the total number of visiting fishermen had increased to 2,400 but then a decline set in and by the end of the century the visitors had ceased to come. The accounts from 1513 show that the Danish fishermen operated very large vessels, a total of 45 with an average crew of 9.4 men, evidently built for long journeys into the North Sea and not just for inshore Wadden Sea operations, while the German vessels were smaller, probably reflecting the fact that their journey was shorter (Poulsen 1998).

In addition to the offshore Helgoland fishery, the Danish fishermen conducted a local fishery in the Wadden Sea, especially in the spring months from March to June. Investigation of the fishing villages of Sønderside and Vesterside near Blåvand has brought out the richness of the fisheries. The settlements are today covered by sand, but archaeological-historical research shows that they attracted several hundred fishermen and many more helpers and traders during the fishing season (Frandsen 1998; Holm 1998). The Wadden Sea islands of Fanø and Mandø were equally important in the fishery but archaeological investigations have not yet informed us of the settlement.

Consequently, the main source of information on the fisheries comes from the tax lists for the King's estate of Riberhus which covered the entire area of the present Danish Wadden Sea (Holm and Bager 2001). The accounts reveal that the fisheries were mainly concentrated on plaice and haddock, but other species such as cod
(Gadus morhua) and rays (Raiidae) were also targeted. The taxes of 1562 can be estimated to correspond to total landings in the region of 1,200 metric tonnes of haddock and 1,800 tonnes of plaice (calculated from Holm 1999). The catches were probably extracted from a relatively small part of the Reef of the Horn area, probably within one or two days' sailing. Evidently, the commercial fishery in the Wadden Sea was richer in the medieval period than in modern times. The haddock landings of 1562 were double the amount of the peak of 1890 at Hjerting. The total landing of 3,000 metric tonnes, plus what was landed in other species, in 1562 is equivalent to present-day landings of a large North Sea fishing port like Hvide Sande (Holm 1999).

Overall, the tax accounts bring out a picture of relative decline from the high point in 1562 , through a relatively stable period with catches around 1,500 tonnes in the first quarter of the seventeenth century to a depressed state of catches around 500 tonnes in the second quarter of the century (Holm and Bager 2001). At the same time, the fishing fleet dropped from 150 vessels in 1582 , crewed by more than 1,200 fishermen, to 115 vessels in 1625 and 80 in 1642. The settlements of Sønderside and Vesterside were, in fact, abandoned before the end of the seventeenth century, while the fishery of Fanø survived at a much reduced scale into the better haddock fishery conditions that were experienced in the last half of the eighteenth century as we saw above (Holm 1999).

It is not clear if stock fluctuations or adverse market conditions caused the decline in the catches. Declining catches per unit effort may point to declining stocks as the ultimate cause. A single hand-lining fisherman caught an average of 1,516 haddock in 1582 , but in 1625 the average was down to 991, while results were better in 1642 with 1,257 haddock. When the full data sets are published as a result of ongoing work by Maibritt Bager, we may detect a clear correlation.

Overall, the evidence for the medieval and early modern period indicates that the fisheries were much more productive than in later periods. We still need more research to establish the correlation between climate and fishing pressure as possible drivers for the decline of the captures by the mid-seventeenth century.

\section{Conclusions}

This review indicates that the abundance of finfishes have undergone a long-term decline since the seventeenth century. Early modern (sixteenth- and seventeenth-century) fisheries were based on ample fisheries resources of cod, herring and plaice. Indications of reduced fisheries were clear by the seventeenth century but the reasons for the decline cannot be ascertained at present. The nineteenth century saw renewed large catches of haddock, but by the end of the century large fish such as sturgeon were fished out, and by the early twentieth century haddock and rays were effectively 
extinct from the region. The review also indicates a trajectory of ecological decline since the early twentieth century that seems to be related to: (1) fishing extractions which focused on undersized fish through the first half of the twentieth century; (2) habitat destruction, which was most marked in the first half of the twentieth century; and (3) pollution, which was worst in the third quarter of the twentieth century. Abundant species, such as plaice, became less abundant in the first half of the twentieth century, and by about 1950 the fishery of the Danish Wadden Sea region was severely depleted to a degree that it was no longer able to sustain commercial finfisheries. In the 1960s, shrimp fishery was introduced but conservation measures were soon needed. Today, only cockle and mussel fisheries are commercially viable, but conservation reports indicate that the mussel beds have been subject to considerable reduction due to both natural and human impacts.

Acknowledgements I want to thank Dr. Heike Lotze for inviting me to write this review and for her help throughout. I thank Prof. Wim J. Wolff, Dr. Frits Loomeijer and Dr. Brian MacKenzie for valuable suggestions to improve the text. I am also grateful for comments to a draft of the paper by my colleagues Maibritt Bager, Mette Guldberg, Bo Poulsen, René Taudal Poulsen, Martin Rheinheimer and Morten Karnøe Søndergaard. The research was conducted for the History of Marine Animal Populations project of the Census of Marine Life.

\section{References}

Dieperink C (2002) Fangster af laksefisk fra Skjern Å og Storåen. DFU-rapport 100-02, ISBN 87-90968-19-0

Frandsen LB (1998) På jagt efter fiskerlejet Sønderside-arkæologiske undersøgelser, Mark og Montre, pp 61-68

Hedger R, McKenzie E, Heath M, Wright P, Scott B, Gallego A, Andrews J (2004) Analysis of the spatial distributions of mature cod (Gadus morhua) and haddock (Melanogrammus aeglefinus) abundance in the North Sea (1980-1999) using generalised additive models. Fish Res 70:17-25

Holm P (1988) Vadehavsfiskere, Mark og Montre, pp 31-35

Holm P (1992) Hjerting - et maritimt lokalsamfund - midt i verden, Esbjerg

Holm P (ed) (1994) Det sydligeVesterhav. In: Fiskere og Farvande P, Esbjerg, pp 465-544
Holm P (1998) Sønderside-fiskerleje og handelsplads. Mark og Montre 1998, pp 69-80

Holm P (1999) Fiskeriets økonomiske betydning i Danmark, 1350 1650. Sjæk'len 1998 (Esbjerg), pp 9-42

Holm P, Bager M (2001) The Danish Fisheries, c. 1450-1800: medieval and early modern sources and their potential for marine environmental history. In: Holm P, Smith TD, Starkey DJ (eds) The exploited seas: new directions for marine environmental history. Research in maritime history 21. (International Maritime Economic History Association / Census of Marine Life, St. John's Newfoundland, 2001, St. John's), pp 97-122

Holm P, Byskov S, Toft S (1998) Proteiner fra havet. Fiskemelsindustrien i Esbjerg, 1948-1998, Esbjerg

Jepsen N, Deacon M, Ejby-Ernst M (2003) Laksens gydevandring i Varde A systemet Radiotelemetri-undersøgelse. DFU-rapport 125-03, ISBN 87-90968-50-6

Kristensen PS, Hedegaard A (2002) Hesterejer (Crangon crangon) - køns-og størrelsesfordelinger-i danske fangster og landinger fra Nordsøen, 2001. DFU-rapport 102-02, ISBN 8790968-21-2

Kristensen PS, Pihl NJ (2003) Blåmuslingebestanden i det danske Vadehav efteråret 2002. DFU-Rapport nr.122-03, ISBN 87 90968-44-1

Kristensen PS, Pihl NJ, Hansen A (2002) Hjertemuslinger (Cerastoderma edule) på fiskebankerne omkring Grådyb i Vadehavet, 2002. DFU-rapport nr. 108-02, ISBN 87-90968-27-1

Kromann NM (1934) Fanøs Historie. I-III; Esbjerg

LANCEWAD (2001) LANCEWAD. Landscape and cultural heritage in the Wadden Sea Region-Project report. Wadden Sea Ecosystem No. 12-2001

Lotze HK (2005) Radical changes in the Wadden Sea fauna and flora over the last 2,000 years. Helgol Mar Res (in press)

Lozan J, Lenz W, Rachor E, Watermann B, von Westernhagen H (eds) (1990) Warnsignale aus der Nordsee. Paul Parey-Verlag, Berlin

Lozan J, Rachor E, Reise K, von Westernhagen H, Lenz W (eds) (1994) Warnsignale aus dem Wattenmeer. Blackwell Wissenschaftsverlag, Berlin

Møller A (1973) Både og Bådfolk i Marsken. Esbjerg, ISBN 8787453-04-5

Nielsen EE, Koed A (2000) En nål i en høstak-genetiske undersøgelser af danske laksebestande. M\&V Miljø-og Vandpleje 25:9-13

Poulsen B (1998) The herring fisheries at Heligoland, c.1330-1550. In: Holm P, Starkey DJ (eds) North Atlantic Fisheries. Markets and Modernisation, Studia Atlantica 2 Esbjerg, pp 7-37

Udkast (2002) Udkast til Forvaltningsplan for spættet sæl (Phoca vitulina) og gråsæl (Halichoerus grypus) i Danmark. http:// www.skovognatur.dk/erhvogadm/hoeringer/saeler/ 